原著

\title{
ヒト喠液腺多形性腺腫における間質型（I）および 軟骨型（II，IX）コラーゲン分布の免疫組織化学的検索
}

\author{
フロレス ルナ マリアグアダルッペ \\ 東京医科歯科大学歯学部口腔病理学講座（主任：高木 実教授）
}

(1995 年 12 月 8 日 受付)

\author{
Immunohistochemical Localization of Type I, II \\ and IX Collagens in Pleomorphic Adenoma of Human Salivary Glands
}

Maria Guadalupe Flores Luna

\begin{abstract}
Department of Oral Pathology, Faculty of Dentistry, Tokyo Medical and Dental University (Chief : Prof. Minoru Takagi)
\end{abstract}

\begin{abstract}
The expression patterns of type I, II and IX collagens in chondromyxoid tissue of salivary pleomorphic adenomas were examined by immunohistochemistry. In the early stage of cartilage development, type IX collagen was detected intracytoplasmically, mainly in the proliferating myoepithelial cells and not in the extracellular matrix. Proliferating myoepithelial cells did not show chondrocytic characteristics at this stage. Type I and II collagens were co-distributed in the extracellular matrix of myxoid tissue. In the chondroid tissue, variable immunostaining patterns of type I and II collagens were also observed. Some proliferating myoepithelial cells in myxoid and chondroid tissue were immunostained with anti- $\alpha$-smooth muscle actin antibody indicating their myoepithelial origin. These results suggested that proliferating myoepithelial cells may be the origin of the chondroid tissue and the expression of type IX collagen in cartilaginous tissue precedes the expression of type I and II collagens.
\end{abstract}

\section{I。緒言}

大小唾液腺に発生し最も頻度の高い良性腫瘍で ある多形性腺腫 (pleomorphic adenoma：PA) は，上皮組織由来の腫瘍であり，筋上皮細胞およ び導管細胞に分化できる多機能的な介在導管細胞 から発生すると考えられている ${ }^{1 \sim 4)}$

多形性腺腫は, 粘液腫様, 軟骨様組織, 硝子様 組織 およびまれには骨様組織を腫瘍間質として 有することが特徵である5
ヒトの乳腺においては多形性腺腫は主に女性に 生じるが, 頻度の低い腫瘍であり, 骨化生が病理 組織学的特徵である点に違いがあるものの唾液腺 にできる多形性腺腫と非常に類似している6)。

ラットの唾液腺腺腫の実験では, 筋上皮細胞が 多形性腺腫の腫瘍発生に重要な役割を果たしてい ることが示唆されている7)。超微細構造と免疫組 織化学の検索により, 介在導管にみられる筋上皮 細胞は筋特異なアクチン，ミオシンを含み，サイ トケラチン陽性であることが証明された ${ }^{8,9)}$ 。正常 
発生下では硝子軟骨の形成は, 間葉細胞が集合し, 軟骨細胞系へと分化した時に生じる10)。

硝子軟骨は種々の型のコラーゲン，プロテオグ リカンおよび他の蛋白成分を含んでおり，コラー ゲンは少なくとも遺伝子的に異なった 5 種の分 子， II，VI，IX，X，XI型が主要な成分である。 I 型コラーゲンは線維芽細胞および骨芽細胞で産 生される主要なコラーゲンで, 皮膚, 腱, 靶帯,

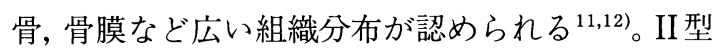
コラーゲンは $\alpha 1$ (II) 鎖のホモトライマーであ $\eta$ ，軟骨基質の主な線維性成分である ${ }^{13,14)}$ 。また， IX型コラーゲンは硝子軟骨および胎児軟骨に見い 出され ${ }^{15}$, 分子は $\alpha 1$ (IX) 鎖, $\alpha 2$ (IX) 鎖と $\alpha 3$ (IX) 鎖の 3 つの遺伝子産物からなり，各鎖は 4 つの非 ヘリカル領域を含む特異なコラーゲンである。IX 型コラーゲンはII型コラーゲン線維上で共有結合 しており ${ }^{16,17)}$, II 型コラーゲン線維の太さを調節 し，さらに細胞周囲のマトリックスとの相互作用 をも調節する役割を果たしているようであ $3^{16,18,19)}$

本研究は軟骨組織の発生および調節機構を明ら かにするために，七ト唾液腺多形性腺腫の化生軟 骨における軟骨型（II，IX型）コラーゲンおよび 間質型（I 型）コラーゲンの発現を免疫組織学的 手法を用いて検索したところ，七卜唾液腺多形性 腺腫における軟骨化生でも, 犬乳腺多形性腺 腫 $^{20,21)}$ 同様に軟骨型コラーゲンが新たに発現さ れたことを明らかにした。

\section{II. 材料および方法}

\section{1. 試料}

唾液腺多形性腺腫患者 20 例および正常顎下腺 3 例から採取した組織をただちにメタノール・カ ルノワ溶液中で $4{ }^{\circ} \mathrm{C} 1 \sim 2$ 時間固定した。正常七 卜新生児肋軟骨組織は $4 \%$ パラホルムアルデヒド / 0.1 M リン酸緩衝液 ( $\mathrm{pH} 7.4$ ) 中で上記と同様 に固定した。固定組織は脱水, キシレンで透徹後, パラフィン (Paraplast Xtra, 融点 $56 \sim 57^{\circ} \mathrm{C}$ ) に 包埋した。標本は $4 \mu \mathrm{m}$ の厚さに薄切し, ヘマトキ シリンーエオジンおよびアルシアンブルー
（pH 2.5）で染色し， 試料中の粘液腫様組織およ び軟骨様組織の存在と分布を検索し，16 例につき 免疫組織学的検索を行った。

\section{2. 免疫組織染色用一次抗体}

一次抗体は，ヒトの皮膚由来 I 型コラーゲンに 対する単クローン抗体 (マウス IgG, 1：500 希 釈, コスモ社), ヒト肋軟骨由来抗II型コラーゲン に対する単クローン抗体 (マウス IgG, $1 ： 250$ 希 釈, 富士薬品工業), ヒト硝子軟骨由来IX型コラー ゲン対するポリクローン抗体(ラット IgG, $1 ： 50$ 希釈，金沢大学川島篤弘博士から供与), $\alpha$ smooth muscle actin ( $\alpha$-SMA) に対する単ク ローン抗体（マウス IgG，1：50 希釈，Dakopatts, Denmark) およびサイトケラチン KL 1 に対する単クローン抗体 (マウス IgG，1：200 希 勫，コスモ社）を使用した。抗 $\alpha$-SMA 抗体と抗 サイトケラチン抗体は正常筋上皮細胞および導管 細胞のマーカーとして使用した。なお抗 I 型コ ラーゲン抗体と抗II型コラーゲン抗体間の交叉反 応がないことは ELISA 法にて確認した。

\section{3. 免疫組織染色}

免疫組織染色は上記一次抗体, ビオチン化二次 抗体およびアビジン化ペルオキシダーゼを用いる $\mathrm{ABC}$ 法 (ベクスタチンキット，ベクター社）にて 行った。組織切片は常法により脱パラフィン後, $50 \mathrm{mM}$ トリス塩酸緩衝液 $\mathrm{pH} 7.6 / 0.15 \mathrm{M} \mathrm{NaCl}$ (トリス-生食液)で洗浄した。内因性ペルオキシ ダーゼを除去するために，組織切片を $0.5 \%$ 過 ヨ ウ素酸溶液に室温で 30 分浸し，ついで $0.5 \%$ ガ インノトリス-生食液で $37^{\circ} \mathrm{C} ， 1$ 時間反応した。一 次抗体を添加し $4{ }^{\circ} \mathrm{C}$ 一晚静置した。但し, I, II, IX型コラーゲンに対する抗体との免疫反応では, 軟骨組織中のプロテオグリカン（酸性ムコ多糖） による抗原決定基のマスクを除去する目的で22) $5 \%$ ヒアルロニダーゼ(ウシ睪丸由来, シグマ社)/ 酶酸ナトリウム緩衝液 $\mathrm{pH} 5.0$ で $37^{\circ} \mathrm{C}, 30$ 分間反 応した。トリス-生食液で洗浄後二次抗体(ビオチ ン化抗マウス IgG ウマ抗体／トリス-生食液で希 釈 $1 ： 200)$ を添加し, $37^{\circ} \mathrm{C} 1$ 時間反応した。トリ ス-生食液で洗浄後ペルオキシダーゼ標識ビオチ 
ンーアビジン複合体（1：100）とさらに 1 時間室 温にて反応した。組織切片は過酸化水素水 （0.03\%）添加ジアミノベンチジンを基質として 発色させ,へマトキシリンにて対比染色を施し( 1 ～2 秒), 脱水, 透徽後 HRS（ミドリ十字社）に て封入した。陰性対照として特異的一次抗体のか わりに正常マウスの血清を希釈して使用した。

\section{III. 結果}

多形性腺腫は顎下腺, 耳下腺, 上口唇腺, 口蓋 腺から採取した 16 例を検索した（表 1 ）。患者の 年齢および性別は $22 \sim 77$ 歳, 男性 7 例, 女性 9 例 であった。得られた多形性腺腫組織 16 例の組織学 的検索ではこの腫瘍に特徵的な多彩な像，すなわ ち腫瘍細胞, 粘液腫様組織, 軟骨様組織, および 硝子様組織が混在する腺腫様部位が認められた。 腺腫様部分では，腺管形成をする細胞として 2 種 すなわち, 内層上皮細胞および外層上皮細胞が認 めることがあり，また充実性細胞集塊を形成する
こともある。粘液腫様組織と軟骨様組織の分布の 比率は個々の症例で変化が認められた。

\section{1. 多形性腺腫の免疫組織化学的検索}

多形性腺腫組織における各型（I, II, IX）コ ラーゲンの抗体に対する免疫組織染色像の観察結 果を表 2 に示した。

多形性腺腫の免疫組織化学的検索では，粘液腫 様組織で増殖性筋上皮細胞にIX型コラーゲンが細 胞形質内に強陽性に検出されたが，細胞外マト リックスには観察されなかった（図 $1 \mathrm{a}$ )。この粘 液腫様組織では増殖性筋上皮細胞は軟骨細胞様の 性状を示さなかった。これらの症例の内, 症例 2 は腺管外層上皮細胞および充実性細胞集塊が抗IX 型コラーゲン抗体で染色されなかったが，この組 織標本には粘液腫様組織がそしく軟骨様組織が主 であった。

II 型コラーゲンについては新生児肋軟骨が，抗 II 型コラーゲン抗体により中等度に陽性像を示し た。多形性腺腫の粘液腫様組織の細胞外マトリッ

表 1 唾液腺に発生した多形性腺腫 16 例の軟骨粘液腫様組織の分布

\begin{tabular}{|c|c|c|c|c|c|}
\hline \multirow{2}{*}{$\begin{array}{l}\text { 症例 } \\
\text { 番号 }\end{array}$} & \multirow{2}{*}{ 年齢 } & \multirow{2}{*}{ 性 } & \multirow{2}{*}{ 部位 } & \multicolumn{2}{|c|}{ 組織学的特徵 } \\
\hline & & & & 粘液腫様組織 & 軟骨様組織 \\
\hline 1 & 38 & 女 & 顎下腺 & + & + \\
\hline 2 & 39 & 男 & 顎下腺 & + & + \\
\hline 3 & 42 & 男 & 口蓋腺 & + & + \\
\hline 4 & 53 & 女 & 耳下腺 & + & $\diamond$ \\
\hline 5 & 40 & 女 & 耳下腺 & + & + \\
\hline 6 & 24 & 女 & 耳下腺 & + & + \\
\hline 7 & 24 & 女 & 顎下腺 & + & + \\
\hline 8 & 51 & 女 & 口蓋腺 & + & $\diamond$ \\
\hline 9 & 41 & 男 & 耳下腺 & + & + \\
\hline 10 & 77 & 男 & 口蓋腺 & + & $\diamond$ \\
\hline 11 & 37 & 男 & 耳下腺 & + & + \\
\hline 12 & 60 & 男 & 耳下腺 & + & + \\
\hline 13 & 75 & 女 & 口蓋腺 & + & + \\
\hline 14 & 47 & 女 & 顎下腺 & + & + \\
\hline 15 & 52 & 女 & 口蓋腺 & + & $\diamond$ \\
\hline 16 & 58 & 男 & 上口唇腺 & + & + \\
\hline
\end{tabular}

+ detected, $\diamond$ non-detected 
表 2 唾液腺に発生した多形性腺腫 16 例の I, II, IX型コラーゲンの免疫組織化学的 検索

\begin{tabular}{|c|c|c|c|c|c|c|c|}
\hline \multirow{4}{*}{$\begin{array}{l}\text { 症例 } \\
\text { 番号 }\end{array}$} & \multirow{2}{*}{\multicolumn{2}{|c|}{ I 型 }} & ラ & - & \multicolumn{3}{|l|}{ ン } \\
\hline & & & & & & IX型 & \\
\hline & \multirow{2}{*}{$\begin{array}{c}\text { 粘液腫様 } \\
\text { 組織 }\end{array}$} & \multirow{2}{*}{$\begin{array}{c}\text { 軟骨様 } \\
\text { 組織 }\end{array}$} & \multirow{2}{*}{$\begin{array}{c}\text { 粘液腫様 } \\
\text { 組織 }\end{array}$} & \multirow{2}{*}{$\begin{array}{c}\text { 軟骨様 } \\
\text { 組織 }\end{array}$} & \multicolumn{2}{|c|}{ 増殖性腺管 } & \multirow[b]{2}{*}{$\begin{array}{c}\text { 粘液腫樣 } \\
\text { 組織 }\end{array}$} \\
\hline & & & & & $\begin{array}{c}\text { 内層上皮 } \\
\text { 細胞 }\end{array}$ & $\begin{array}{c}\text { 外層上皮 } \\
\text { 細胞 }\end{array}$ & \\
\hline 1 & + & $+1+$ & + & $+H$ & - & $H$ & $H$ \\
\hline 2 & + & $H+$ & + & $H$ & - & - & - \\
\hline 3 & + & $+1+$ & $H$ & $+1+$ & - & $H+$ & $H+$ \\
\hline 4 & $H$ & $\diamond$ & - & $\diamond$ & - & + & + \\
\hline 5 & ++ & $H+$ & $H$ & $H+$ & & & \\
\hline 6 & $H$ & $H$ & $H$ & $H$ & & & \\
\hline 7 & + & $H+$ & H & + & & & \\
\hline 8 & + & $\diamond$ & - & $\diamond$ & & & \\
\hline 9 & + & $H$ & H & H+ & & & \\
\hline 10 & + & $\diamond$ & - & $\diamond$ & & & \\
\hline 11 & + & H+ & H & H+ & & & \\
\hline 12 & H+ & $H$ & + & $H+$ & & & \\
\hline 13 & + & $H+$ & - & + & & & \\
\hline 14 & $H+$ & $H$ & H & H+ & & & \\
\hline 15 & $+1+$ & $\diamond$ & ++ & $\diamond$ & & & \\
\hline 16 & H+ & $H+$ & $H$ & H+ & & & \\
\hline
\end{tabular}

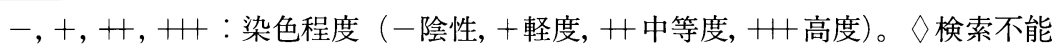

クスでは抗II型コラーゲン抗体に対して中等度に 染色像が観察された（図 $1 \mathrm{~b}$ )。さらにこの粘液腫 様組織の細胞外マトリックスでは抗 I 型コラーゲ ン抗体が種々の異なった陽性染色像を示した（図 $1 \mathrm{c})$ 。増殖性腺管外層上皮細胞に抗IX型コラーゲ ン抗体が強陽性染色に観察された（図 2 a)。充実 性細胞集塊および増殖性腺管周囲上皮細胞は，筋 上皮細胞のマーカーである $\alpha$-SMAに強陽性で あった（図 $2 \mathrm{~b}$ )。また血管壁も $\alpha$-SMAに陽性で あった。

多形性腺腫の軟骨様組織では抗IX型コラーゲン 抗体に対して細胞外マトリックスに軽度の染色像 が観察されたが，軟骨細胞は全く染色されなかっ た（図 $3 \mathrm{a} ）$ 。軟骨様組織で細胞外マトリックスは 抗II 型コラーゲン抗体で種々の異なった陽性像を
示した（図 3 b)。さらに抗 I 型コラーゲン抗体で 強い陽性像が観察された（図 $3 \mathrm{c}$ )。I 型およびII 型コラーゲンはともにこれら軟骨粘液腫様組織の 細胞外マトリックスに分布していた。陰性対照 (正 常マウス血清使用) では, いずれも陽性染色像は 認められなかった。

\section{IV. 考察}

本研究の結果の要約を図 4 に示す。唾液腺多形 性腺腫の軟骨様の組織発生過程における各型コ ラーゲン発現の移行のパターンを示している。IX 型コラーゲンは粘液腫様組織において増殖性筋上 皮細胞の細胞質内に認められ，細胞外マトリック スへの沈着は認められなかった。またこの粘液腫 様組織での增殖性筋上皮細胞は軟骨細胞様の染色 


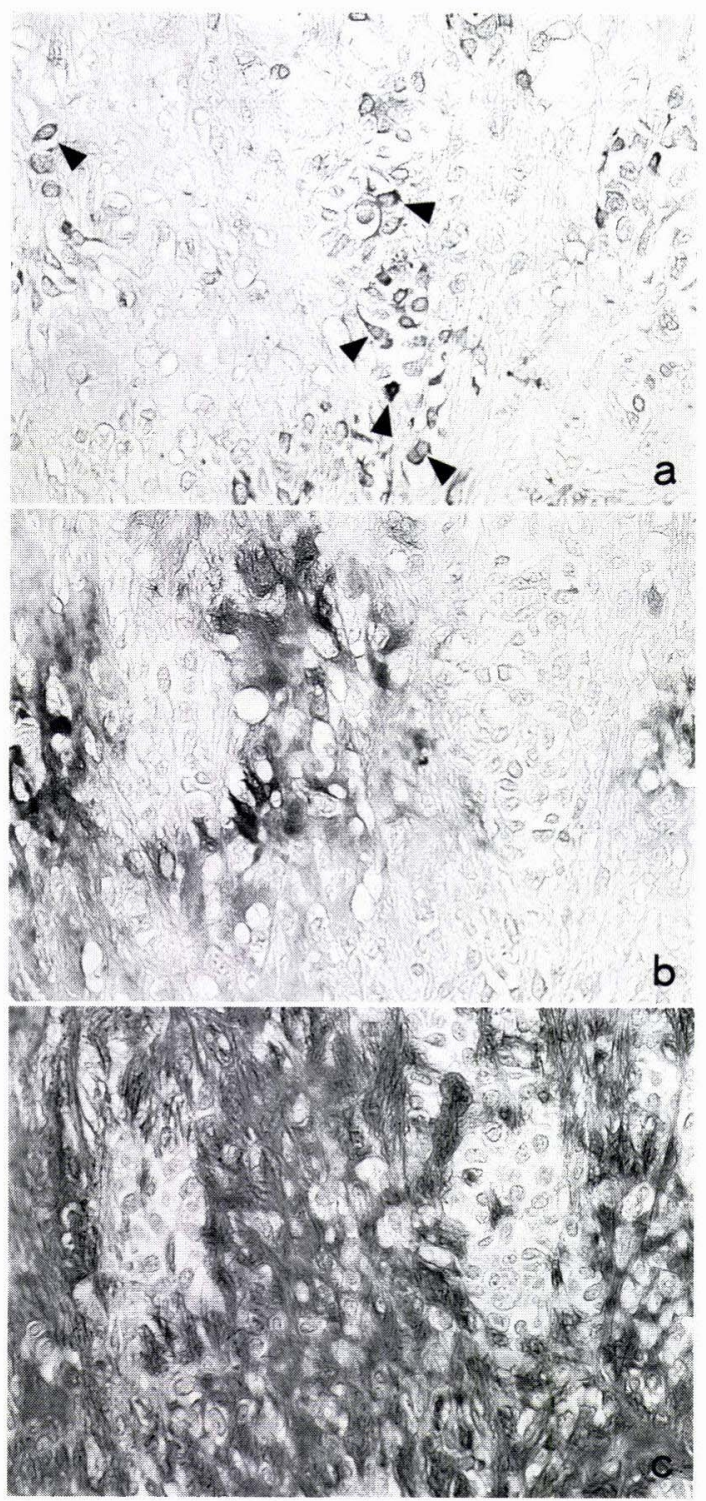

図1 多形性腺腫の粘液腫様組織の免疫組織化学的 所見

a）増殖性筋上皮細胞に抗IX型コラーゲン抗体 に対して陽性所見がみられた（アローへッド）。

b ) 粘液腫様組織の細胞外マトリックスに抗 II 型コラーゲン抗体に対して陽性所見がみられ た。

c） b と同様，細胞外マトリックスに抗 I 型コ ラーゲン抗体に対して陽性所見がみられた。a $\sim c: \times 270$

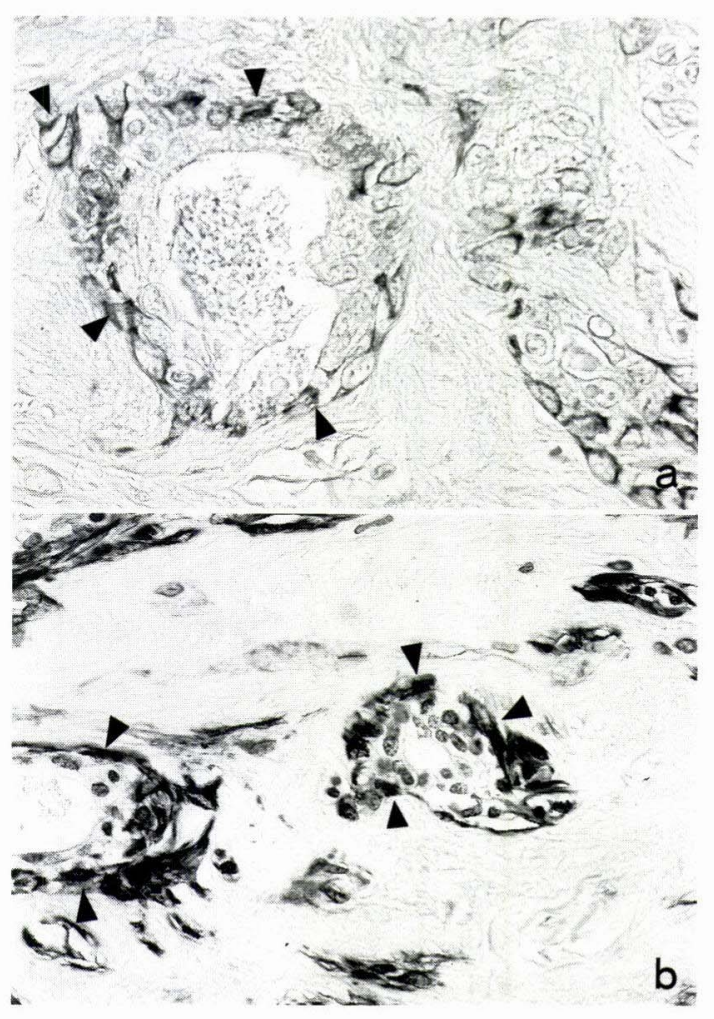

図 2 増殖性腺管の免疫組織化学的所見

a ）増殖性筋上皮細胞では抗IXコラーゲン抗体 に対して陽性所見がみられた（アローヘッド） b ) 増殖性腺管外層上皮細胞では抗 $\alpha$-SMA 抗 体に対して陽性所見がみられた（アローへッ ド)。 a, b : $\times 420$

像を示さなかった。さらにIX型コラーゲンは増殖 性腺管外層上皮細胞にも検出された。I 型および II 型コラーゲンは粘液腫様組織および軟骨様組織 の細胞外マトリックスに両者ともに局在してい た。これらの結果はIX型コラーゲンが I 型および II 型コラーゲンの沈着前に検出されることを意味 しているが, Swiderski ら ${ }^{23)}$ は, 肋軟骨においてIX 型コラーゲンとII型コラーゲンは同時発現し, IX 型コラーゲンはII型コラーゲン線維に共重合され ると報告している ${ }^{18)}$ 。

七ト乳腺多形性腺腫は頻度の低い良性腫瘍であ るが6)，イヌの乳腺多形性腺腫は頻度が高い腫瘍 であることが知られている20)。乳腺は唾液腺のよ 


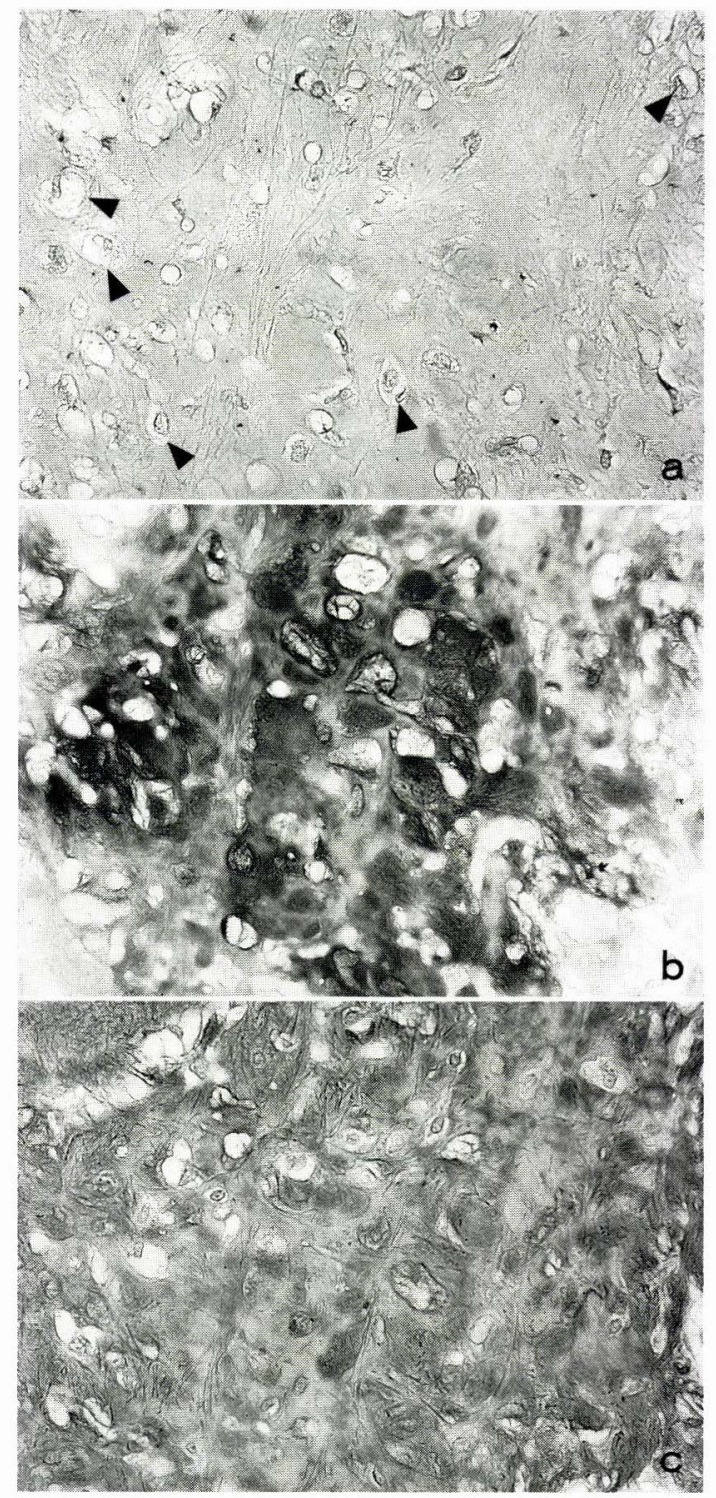

図 3 軟骨様組織の免疫組織化学的所見

a ) 抗IX型コラーゲン抗体に対して染色所見が みられなかった。アローへッドは軟骨細胞を示 す。

b ）抗II型コラーゲン抗体に対して染色所見が みられた。

c）抗I 型コラーゲン抗体に対して染色所見が みられた。 $\mathrm{a} \sim \mathrm{c}: \times 270$

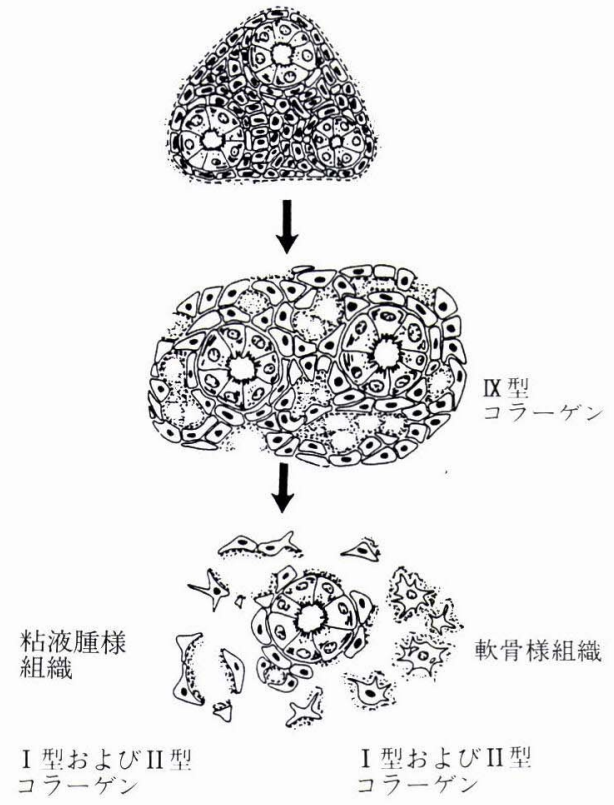

困 4 唾液腺多形性腺腫の軟骨粘液腫様組織 の発生過程におけるIX型，I 型およびII 型コラーゲン発現のパターン

うな上皮組織由来の腺である7)。光学顕微鏡的観 察によると, 乳腺の多形性腺腫は骨化生性組織が 形成される点でヒト唾液腺多形性腺腫と差異があ るが基本的には両者はよく似ている。Arai ら ${ }^{20}$ は，これまでイ邓乳腺多形性腺腫の軟骨様組織に おいてII型コラーゲンの沈着があることを報告し ている。さらに最近の免疫組織学的検索において イヌ乳腺多形性腺腫の早期の軟骨様組織の発生過 程でIX型コラーゲンの発現が証明されている ${ }^{24)}$ IX型コラーゲンは種特異的ならびに組織特異的な 発生をしたと考之られる病理像を示す。七卜唾液 腺多形性腺腫のII型およびIX型コラーゲンの発現 の時間経過からみるとIX型コラーゲンは軟骨細胞 へと分化する増殖性筋上皮細胞のよいマーカーと なると示唆され，このIX型コラーゲンはごく早期 の軟骨様組織の発生において増殖促進作用のよj な重要な役割を果たしているかもしれない。数種 の細胞系においてII型およびIX型コラーゲンの発 現と腫瘍抑制遺伝子の関連が報告されている ${ }^{25)}$ 。 Kawashima ら ${ }^{26)}$ は内生軟骨腫および原発性軟骨 
肉腫の軟骨組織において, IX型コラーゲンは他の 型のコラーゲンが発現する前に不規則に分布して おり，IX型コラーゲンが腫瘍の悪性度の決める情 報を与之る可能性を示唆している。

本研究においては, 免疫組織化学的手法によっ て，I 型およびII型コラーゲンが軟骨粘液腫様組 織にともに局在していることを明らかにした。現 在子備的な in situ ハイブリダイゼーション実験 では I 型コラーゲンの mRNA が粘液腫様組織の 増殖性筋上皮細胞に低レベルではあるが検出され ている(未発表デー夕)。これの予備実験のデー夕 は I 型コラーゲンが増殖性筋上皮細胞により産生 された可能性を示唆している。

Takeuchi ら ${ }^{27)}$ およ゙ Nara ${ }^{28}$ は粘液腫様部 位にプロテオグリカンおよび他の糖蛋白質が存在 していることを同定した。これらの物質の産生に おける筋上皮細胞の役割は最終的には証明されて いないが，プロテオグリカンおよび糖蛋白の存在 は増殖性筋上皮細胞が軟骨様組織の発生に関与し ている可能性を示唆する。一方, Arai ら ${ }^{20}$ は増殖 性筋上皮細胞はアルシアンブルー陽性の結節塊を 形成することを示した。本研究の症例でもアルシ アンブルー陽性酸性ムコ多糖が軟骨様組織に検出 されている(未発表デー夕)。

\section{V. 結 論}

本研究の結果は増殖性筋上皮細胞が軟骨粘液腫 様組織の起源細胞であり, 増殖腺管の外層上皮細 胞に陽性所見を認めることは介在導管由来の増殖 性筋上皮細胞から, 細胞質にIX型コラーゲンを産 生する軟骨細胞が生ずる可能性を示唆している。 この軟骨細胞は，さらに細胞外マトリックスに沈 着するI 型およびII型コラーゲン産生へと遺伝子 発現が切り替わると考えられる。

\section{謝辞}

稿を終えるに臨み，終始ご㤅篤なるご指導，ご校閲 を賜った本学口腔病理学講座高木 実教授に深く感 謝いたします。また，懇切なるご教示を賜りました難 治疾患研究所異常代謝部門, 永井裕名誉教授,
堀 久枝博士に感謝の念を表します。また, 種々のご 助言をいただきました口腔病理学講座, 勝部憲一博士 に深謝いたします。また，ご教示を賜りました東京農 業工業大学硬蛋白質利用研究施設新井克彦助教授に 深謝いたします。さらに, 本研究にご協力いただきま した口腔病理学講座の皆梯および難治疾患研究所異 常代謝部門木村彰方教授と研究室の皆様に厚くお礼 申し上げます。

また，抗IX型コラーゲン抗体をご恵与下さいました 金沢大学医学部病理講座中西功夫教授, 川島篤弘博士 ならびに正常ヒ卜新生児肋軟骨組織をご恵与下さい ました日本赤十字医療センタ一検査部武村民子部長 に感謝いたします。

\section{文献}

1) Shirasuna, K., Sato, M. and Miyasaki T. : A myoepithelial cell line established from a human pleomorphic adenoma arising in minor salivary gland. Cancer $45: 297-305,1980$.

2) Harrison, J. D. and Auger, D. W. : Ultrastructural observations on luminal structures of pleomorphic adenoma of parotid and submandibular salivary glands of man. Virchows Archiv A Pathol Anat. 415 : 559-563, 1989.

3) Nathrath, W. B., Wilson, P. D. and Trejdosiewicz, L. K. : Immunohistochemical localisation of keratin and luminal epithelial antigen in myoepithelial cells of human mammary and salivary gland tumours. Path Res Pract. 175 : 279-288, 1982.

4) Dardick, I., Gliniecki, M. R., Heathcote, J. G. and Burford-Mason, A. : Comparative histogenesis and morphogenesis of mucoepidermoid carcinoma and pleomorphic adenoma. An ultrastructural study. Virchows Archiv A Pathol Anat. 417 : 405-417, 1990.

5) Ellis, G. L., Auclair, P. L. and Gnepp, D. R. : Surgical Pathology of the Salivary Glands. Philadelphia, PA., 1991, W. B. Saunders, Co., 108-125.

6) Ballance, W. A., Ro, J. Y., El-Naggar, A. K., Grignon, D. J., Ayala, A. G. and Romsdahl, M. G. : Pleomorphic adenoma (benign mixed tumor) of the breast. An immunohistochemical, flow cytometric, and ultrastructural study and review of the literature. Am J Clin Pathol. 93 : 795-801, 1990.

7) Dardick, I., van Nostrand, A. W. P. and Phillips, M. J. : Histogenesis of salivary gland 
pleomorphic adenoma (mixed tumor) with an evaluation of the role of the myoepithelial cell. Hum Pathol. $13: 62-75,1982$.

8) Dardick, I., Rippstein, P., Skimming, L., Boivin, M., Parks, W. R. and Dairkee, S. H. : Immunohistochemistry and ultrastructure of myoepithelium and modified myoepithelium of ducts of human major salivary gland tumors. Oral Surg Oral Med Oral Pathol. 64 : 703-715, 1987.

9) Palmer, R. M. and Lucas, R. B. : Immunocytochemical identification of cell types in pleomorphic adenoma, with particular reference to myoepithelial cells. J Pathol. 146:213-220, 1985.

10) Erlebacher, A., Filvaroff, E. H., Gitelman, S. E. and Derynck, R. : Toward a molecular understanding of skeletal development. Review. Cell $80: 371-378,1995$.

11) Yasui, N., Ono, K., Yamaura, I., Konomi, H. and Nagai, Y. : Immunohistochemical localization of type I, II and III collagens in the ossified posterior longitudinal ligament of the human cervical spine. Calcif Tissue Int. 35 : 159-163, 1983.

12) Alberts, B., Bray,D., Lewis, J., Raff, M., Roberts, K. and Watson, J. D. : Molecular Biology of the Cell. New York, 1994, Garland Publishing Inc., 978-980.

13) Mundlos, S., Engel, H., Michel-Behnke, I. and Zabel, B. : Distribution of type I and type II collagen gene expression during the development of human long bones. Bone $11: 275-279$, 1990.

14) Yasui, N., Ono, K., Konomi, H. and Nagai, Y. : Transitions in collagen types during endochondral ossification in human growth cartilage. Clin Ortho. $183: 215-218,1984$.

15) Wu, J-J., Woods, P. E. and Eyre, D. R. : Identification of cross-linking sites in bovine cartilage type IX collagen reveals an antiparallel type II-type IX molecular relationship and type IX to type IX bonding. J Biol Chem. 267 : 2300723014, 1992.

16) Van der Rest, M. and Mayne, R. : Type IX collagen proteoglycan from cartilage is covalently cross-linked to type II collagen. J Biol Chem. 263 : 1615-1618, 1988.

17) Vasios, G., Nishimura, I., Konomi, H., Van der Rest, M., Ninomiya, Y. and Olsen B. R. : Cartilage type IX collagen-proteoglycan contains a large amino-terminal globular domain encoded by multiple exons. J Biol Chem. $263: 2324$ -
2329, 1988.

18) Nishimura, I., Muragaki, Y. and Olsen, B. R. : Tissue-specific forms of type IX collagenproteoglycan arise from the use of two widely separated promoters. J Biol Chem. 264 : 2003320041, 1989.

19) Van der Rest, M. and Garrone, R. : Collagen family of proteins. FASEB J. 5:2814-2823, 1991.

20) Arai, K., Uehara, K. and Nagai Y. : Expression of type II and type XI collagens in canine mammary mixed tumors and demonstration of collagen production by tumor cells in collagen gel culture. Jpn J Cancer Res. $80: 840-847$, 1989.

21) Arai, K., Uehara, K. and Nagai Y. : Cartilaginous-type collagen expression in mixed tumor (pleomorphic adenoma). In vivo and in vitro studies. Ann New York Acad Sci. 580 : 586588, 1990.

22) Ye, X. J., Terato, K., Nakatani, H.,Cremer, M. A. and Yoo, T. J. : Monoclonal antibodies against bovine type IX collagen (LMW fragment) : production, characterization, and use for immunohistochemical localization studies. J Histochem Cytochem. 39 : 265-271, 1991.

23) Swiderski, R. E. and Solursh, M. : Localization of type II collagen, long form $\alpha$ (IX) collagen, and short form $\alpha 1$ (IX) collagen transcripts in the developing chick notochord and axial skeleton. Develop Dyn. 194:118-127, 1992.

24) Arai, K., Uehara, K. and Nagai, Y. : Simultaneous expression of type IX collagen and an inhibin-related antigen in proliferative myoepithelial cells in pleomorphic adenoma of the canine mammary gland. Jpn J Cancer Res. 86 : 577-584, 1995.

25) Cizdziel, P. E., Hosoi, J., Montgomery, J. C., Wiseman, R. W. and Barret, J. C. : Loss of a tumor supressor gene function is correlated with downregulation of chondrocyte-specific collagen expression in syrian hamster embryo cells. Mol Carcin. 4 : 14-24, 1991.

26) Kawashima, A., Ueda, Y., Tsuchiya, H., Tomita, K., Nagai, Y. and Nakanishi, I. : Immunohistochemical localization of collagenous proteins in cartilaginous tumors: characteristic distribution of type IX collagen. J Cancer Res Clin Oncol. 120：35-40, 1993.

27) Takeuchi, J. and Kato, Y. : Pleomorphic adenoma of salivary gland, with special reference to histochemical and electron microscopic 
studies and biochemical analysis of glycosaminoglycans in vivo and in vitro. Cancer 36: 1771-1789, 1975.

28) Nara, Y., Takeuchi, J., Yoshida, K., Fukatsu, T., Nagasaka, T., Kawaguchi, T., Meng, N.,
Kikuchi, H. and Nakashima, N. : Immunohistochemical characterization of extracellular matrix components of salivary gland tumors. Br J Cancer. 64 : 307-314, 1991. 